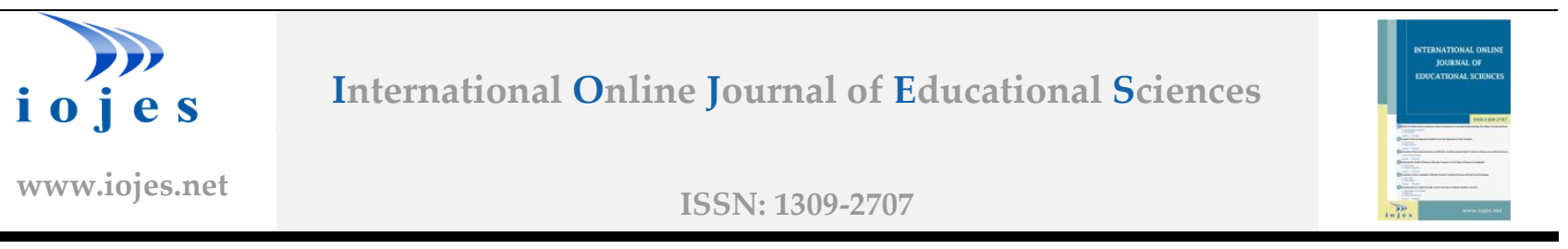

\title{
University Students' Attitudes towards Claiming Right
}

\section{Research Article}

\section{Puren AKCAY ${ }^{1}$, Gul GULER ${ }^{2}$}

${ }^{1}$ Istanbul Aydin University, Faculty of Education, Department of Education Management, Istanbul, Turkey, ORCID: 0000-0002-0087-7561

${ }^{2}$ Istanbul Aydin University, Faculty of Education, Department of Education Management, Istanbul, Turkey, ORCID: 0000-0001-8626-4901

To cite this article: Akcay, P., \& Guler, G. (2021). University students' attitudes towards claiming right, International Online Journal of Educational Sciences, 13(2), 521-535.

\begin{abstract}
ARTICLE INFO
ABSTRACT

Article History:

In this study, it was aimed to determine the attitudes of university students of claiming right. The freedom of claiming right and claiming right remedies have an supervision function that ensures that

Received: 07.09.2020 the responsible authorities fulfill their obligations. Accordingly, positive attitudes towards claiming rights are important in fulfilling this indirect supervision function. Establishing a positive attitude

Available online: towards claiming right by legal ways in the young generation, who will form the democratic and

29.03.2021 liberal structure of the society, will support the existence and continuity of the culture of democracy. This research is a survey model that examines university students' attitudes towards claiming rights in terms of various (gender, parents' education level, family income, faculty, grade, parents' attitude, graduated high school) variables. The research data were obtained from 720 university students studying at 8 universities, 4 foundation and 4 state universities in Istanbul. The research data were obtained by using the "Attitude Scale towards Claiming Rights" and "Personal Information Form" in order to determine the attitudes of university students to claiming rights. "The Attitude Scale towards Claiming Rights' is a five-point Likert type scale consisting of 20 items and four dimensions. According to the findings obtained in the study, significant differences were found in the attitudes of university students towards claiming rights according to their gender, faculty, grade and parents' attitudes.
\end{abstract}

(C) 2021 IOJES. All rights reserved

Keywords:

Freedom of claiming right, attitudes towards claiming right, claiming right remedies university students

\section{Introduction}

The freedom of claiming right and claiming right remedies have an supervision function that ensures that the responsible authorities fulfill their obligations. Accordingly, positive attitudes towards claiming rights are important in fulfilling this indirect supervision function. Establishing a positive attitude towards claiming right by legal ways in the young generation, who will form the democratic and liberal structure of the society,

${ }^{1}$ Corresponding author's address: İstanbul Aydın Üniversitesi

Telephone: +90534 5886483

e-mail: akcaypuren@hotmail.com

DOI: https://doi.org/10.15345/iojes.2021.02.013 
will support the existence and continuity of the culture of democracy. In this study, which aims to determine the attitudes of university students who are the main subjects of higher education institutions, the right to claiming rights and the right to education form the theoretical basis of the research.

\section{Freedom of Claiming Right}

Claiming right is expressed as legal actions that can be taken in order to obtain legally determined interests or to use them as they should. Considering that the basis of the legal system is based on the concept of 'right', the importance of ensuring the freedom to claiming rights becomes evident.

The state, as the greatest authority, is obliged to eliminate violations of rights within its sovereignty (Akın, 1974, p.377). The most important factors showing that the freedom to claiming right exists is that there are suitable and various application methods to protect rights and that these remedies can be used easily. Freedom to claiming rights is generally understood as the precondition and procedural guarantee of rights recognized by positive law (Kaboğlu, 1999, p.95). The freedom to claiming rights is aimed at the provision and realization of all rights and freedoms regulated in the constitution and laws. Therefore, the freedom to claiming rights constitutes a guarantee in itself for obtaining other rights.

The freedom to claiming right is in itself an independent nature. This right aims to protect all other rights regulated in the constitution and laws and shows the means to claiming remedies for this. In this respect, it can be said that the freedom to claiming right is both an independent and an instrument right that ensures the protection of other rights (Çoban, 1995; Kaboğlu, 1999). It is also possible to define the freedom to claiming right as the legal means used to apply to the competent authority and to activate the competent authorities to ensure the protection of positive legal rights (İzgi \& Gören, 2002; Tanör \& Yüzbaşığlu, 2001).

The violated right can easily be obtained by means of remedies and thus justice is provided. In this respect, it would be correct to say that the way to bring a person to justice is through the freedom to claiming right. Administrative applications to administrative authorities, political applications to the parliament and judicial applications to independent courts are legal aspects of the freedom to claiming right. Except for judicial application within the framework of freedom to claiming rights; The existence of political and administrative remedies is a guarantee of the rule of law and democracy.

The freedom to claiming rights is regulated in the "Fundamental Rights and Duties" section of the Constitution. The freedom to claiming rights is regulated under this heading, aiming to protect the individual against the society and especially against the power of the state (Gölcüklü \& Gözübüyük, 2002, p.279). The freedom to claming rights is regulated in the "Fundamental Rights and Duties" section of the Constitution. With the regulation of the right to claiming rights under this heading, it is aimed to protect the individual against the society and especially the power of the state (Gölcüklü \& Gözübüyük, 2002, p.279).

\section{Relationship between Freedom to Claiming Rights and Right to Education}

Within the framework of the concepts of rights and freedoms, the freedom to claiming rights is generally accepted as a prerequisite and a procedural guarantee of the rights granted to individuals by positive law (Kaboğlu, 1999, 95). The development of the individual and society is possible by providing right to education and learning in line with the interests and abilities of everyone. Universal principles regarding rights and freedoms can only come to life in societies with a high level of education (Akyüz, 2001). Education as a strengthening right enables individuals to take their place in the society as conscious citizens (Uyar, 2006, 215). Education as a strengthening right enables individuals to take their place in the society as conscious citizens (Uyar, 2006, 215). In countries that have embraced a libertarian and democratic order, education develops people's creative and critical thinking skills. The benefit of education for the existence of a strong and stable, free and democratic social order is an undeniable fact (Yaşar, 2000, 124). 
It is important to know what the concept of claiming rights means for the individual and society, to be able to actively exercise his rights and freedoms, to claim his rights and to fight for his rights. The most important role in raising and developing this awareness belongs to educational institutions. Education is the most effective instrument in understanding, adopting and implementing fundamental human rights and freedoms. In this context, the right to education has a distinct importance and role among all fundamental rights. From an individual point of view, the right to education has a great importance in knowing, using, developing and protecting other rights and freedoms (Karaman Kepenekçi, 2007). Knowing the meaning of the freedom to claim rights and the effective use of remedies is closely related to the broadest provision of the right to education. When raising awareness of rights through education is accepted as the most appropriate way, the state must first fulfill its obligations to recognize and protect the right and freedom to education and to realize all other elements of the right to education (Akdağ, 1999).

With the realization of the right to education within the framework of universal principles, an increase in social awareness will be observed regarding fundamental rights and freedoms. This increase in social awareness will bring about an increase in the level of awareness and attitude change regarding the freedom to claiming rights. Demanding the state to fulfill its responsibilities regarding the right to education and increasing the awareness of individuals to claiming rights are processes that support each other. The individual, who has the awareness of claiming rights through education, will also be active in demanding his rights and freedoms. The individual will be able to demand the realization of the issues that should be realized by the state regarding the right to education in the most ideal way, with the active role that assumed in claiming rights. It is clear that increasing awareness and changing attitudes through education will increase the quality of exercising the right to education by the authorities.

\section{Legal and Other Ways of Claiming Rights}

Rights can be exercised by applying legal remedies to administrative authorities, the parliament and judicial authorities (Kaboğlu, 1999). Apart from this, there are also ways to claim rights that can be defined as 'Other Ways to Claiming Rights'. The freedom to claiming rights aims to protect the fundamental rights of individuals through different application methods and shows the methods that can be used against the violations of rights that may arise. Individuals try to secure their rights by using different application methods. The main thing is to search for rights using legal remedies, but it is possible to claim rights by using other remedies, albeit exceptional. It is essential that the claim for a right is carried out by a method deemed legitimate by the legal order. As a matter of fact, violence cannot be used during the exercise of the freedom to claiming rights, and it is not possible to resort to illegal means. Other remedies, although recognized by law, emerge unlawfully and in fact, they are not a direct way to see claim remedies, but refer to the procedures that enable and prepare the environment (Çoban, 1995; Kaboğlu, 1999; Özbilgen, p.56). These ways have an important function when individuals cannot fully exercise their legal right to claiming rights or when legal remedies are insufficient. Creating public pressure, exercising the right to demonstrate and march, and the activities of non-governmental organizations are among the most common remedies other than legal remedies.

It is possible to say that the right claiming activity is carried out indirectly by forming public opinion. The public pressure, which is created by the public's attention on a certain subject, discussions on this subject and the increase of similar thoughts on this subject, has a psychological effect. In this way, the rights of the individual or individuals who succeed in attracting the attention of the public will be protected in a sense (Güran, 1993). By using the right to demonstrate and march, which is another form of claiming rights, it is possible to oppose the dominant views in society, to present different ideas, to express their views and opinions in the public sphere, and to defend the interests and views of minorities (Tanyar, 2011).

Non-governmental organizations and activities are also among the remedies to claiming remedies other than legal remedies. Non-governmental organizations are informal organizations based on voluntary 
membership, aimed at serving society and influencing politics (Keyman, 2004). Non-governmental organizations have the characteristic of being organizations that can directly contribute to the development of citizenship awareness (Aktan \& Çoban, 2006).

Educational institutions have the greatest responsibility in ensuring the formation and maintenance of a culture of democracy in our society. The role of higher education institutions is of particular importance within educational institutions. The majority of students in higher education consist of individuals who are over the age of 18, have made their career choices and have reached the end of their education levels. Therefore, how these individuals' attitudes towards seeking rights are shaped will manifest themselves in their private and social lives, professional life and fulfilling their civic responsibilities. The culture of democracy that exists in a society is directly affected by the democratic attitudes and behaviors of individuals. For these reasons, it is important to determine the attitudes of university students to seek remedies. In this direction, taking into account the results obtained from the results of university students' attitudes to seek justice and their attitudes to seek remedies according to various variables, necessary studies can be carried out to establish and raise the culture of democracy in higher education institutions.

\section{The Purpose Of The Research}

The purpose of this study is to determine the attitudes towards university students of claiming right. Within this context, answers to the questions below are sought:

1. What is the level of university students' attitudes towards claiming right?

2. Is there a significant difference in university students' attitudes towards claiming right in terms of gender?

3. Is there a significant difference in university students' attitudes towards claiming right in terms of parents' education levels?

4. Is there a significant difference in university school students' attitudes towards claiming right in terms of family income?

5. Is there a significant difference in university school students' attitudes towards claiming right in terms of faculty?

6. Is there a significant difference in university school students' attitudes towards claiming right in terms of grade?

7. Is there a significant difference in university school students' attitudes towards claiming right in terms of attitudes of parents?

8. Is there a significant difference in university school students' attitudes towards claiming right in terms of type of graduated high school?

\section{Method}

\section{The Research Design}

This descriptive study is designed with survey method. In the survey model research, information is collected from a wide audience by using the answer options determined by the researcher, and the researchers are interested in how the views and characteristics are distributed in terms of the individuals in the sample. (Fraenkel, Wallen, \& Hyun, 2015). 


\section{Sample}

The sample of the study consists of 720 university students studying in 8 universities in Istanbul, 4 private and 4 state, determined by proportional stratified sampling method. While determining the sample of the study, the estimated number of samples $(n=384)$ with a universe size of more than 500.000 and calculated with a deviation of $\mathrm{p}=.05$ was taken into consideration (Çıng1, 1994). The sample of the study consists of 720 university students, $49.5 \%$ of whom are in state university and $50.5 \%$ of whom continue their undergraduate education in a private university in 2018-2019 academic year in Istanbul. Of the students studying at universities determined by cluster sampling, 170 (24\%) education, 172 engineering (24.5\%), 185 law (26.4\%), 176 medicine-dentistry (\%)25,1 consists of faculty students.

\section{Measures}

The research data were collected by using the "Attitudes Towards Claiming Rights Scale" (Akçay \& Güler, 2021), which was prepared to determine the attitudes of university students to claiming rights, including the Personal Information Form.

\section{Personal Information Form}

With the Personal Information Form developed by the researchers, the gender, family income levels, family education levels, grade, faculties, parents attitudes and the high schools they graduated from were determined.

\section{University Students' Attitudes Towards Claiming Rights Scale}

The "Attitude Scale Towards Claiming Rights Scale" used in the study was developed by Akçay and Güler (2021). The scale aims to measure university students' attitudes towards claiming rights. The scale consists of 20 items and four dimensions for claiming rights, each item is answered according to a five-point Likert-type rating (1: strongly disagree; 5: totally agree). Cronbach's alpha internal consistency coefficient of the scale was found to be .90 . Fit indices calculated as a result of the confirmatory factor analysis performed in this study in order to provide evidence for the construct validity of the scale are RMSEA $=.076$; CFI $=.94$; $\mathrm{GFI}=.90 ; \mathrm{NFI}=.92 ; \mathrm{NNFI}=.93$. These values show that the scale is valid and reliable enough for different sample groups (Çokluk, Şekercioğlu, \& Büyüköztürk; 2010, Kline; 2005).

\section{Data Collection}

A questionnaire including demographic information form related to participants and scales are applied to 720 students by researchers in 2018- 2019 academic year. 720 questionnaires of 712 questionnaires were answered by the students.

\section{Data Analysis}

The kurtosis and skewness values of the scores obtained from the scale were examined before examining the relationship between the information collected through the personal information form for the analysis of the data and the scores obtained from the measurement tool. Whether the data provided a multivariate normal distribution was checked with the Barlett Sphericity Test. Since the kurtosis and skewness values of the total score obtained from the scale vary between -1 and +1 , it is accepted that the scores obtained from the scale are normal (Tabachnick \& Fidel, 2007). For this reason, t-test and one-way ANOVA were used for the analysis of the data. The data were analyzed in SPSS 17.0 program.

\section{Findings}

In this section, level of students' attitude towards claiming right is determined. Also students' attitude towards claiming right are compared separately in terms of gender, parents' education levels, family income, faculty, grade, attitudes of parents and type of high school they graduated from. 


\section{Level of Students' Attitude towards Claiming Right}

Table 1 indicates the descriptive analysis results related to level of students' attitude towards claiming rights.

Table 1. Descriptive Analysis Results of University Students' Attitude Scores for Claiming Rights

\begin{tabular}{lccccc}
\hline & $\mathbf{n}$ & $\mathbf{M}$ & SD & Min. & Max. \\
\hline Attitude Towards Claiming Right & 703 & 82,11 & 10,27 & 50 & 100 \\
\hline
\end{tabular}

When the means of the students obtained from the scale for claiming rights are examined, it is seen that their attitudes of claiming rights are above the average (Xort $=82.11>60)$.

\section{Students' Attitude towards Claiming Rights in terms of Gender}

Indepedent sample t-test is used to determine whether the students' attitude towards claiming rights differ in terms of gender. The results of indepedent sample t-test are indicated in table 2.

Table 2. $\mathrm{t}$ test result related to students' attitude towards claiming rights in terms of gender

\begin{tabular}{ccccccc}
\hline Gender & $\mathbf{n}$ & $\mathbf{M}$ & $\mathbf{S}$ & $\mathbf{s d}$ & $\mathbf{t}$ & $\mathbf{p}$ \\
\hline Female & 366 & 83,7 & 9,7 & 694 & 4,371 &, $000^{*}$ \\
Male & 330 & 80,3 & 10,6 & & & \\
\hline${ }^{*} \mathrm{p}<.05$ & & & & &
\end{tabular}

A significant difference was found in the attitudes of university students towards claiming rights according to their gender $(\mathrm{t}(694)=4,371 ; \mathrm{p}<0.01)$. Female students' attitudes towards claiming rights were found to be more positive than male students (Xmeanfemale $=83.7>$ Xmeanmale $=80.3) \mathrm{n} 2=0.02$, eta square value was found. Since this value is greater than 0.01 (Cohen, 1988), it can be stated that gender causes a moderate effect on students' attitudes towards claiming rights.

\section{Students' Attitude towards Claiming Rights in terms of Parents' Education Levels}

One-way ANOVA is used to compare whether the students' attitude towards claiming rights in terms of education level of their parents'. The results are indicated in Table 3 and Table 4.

Table 3. One way ANOVA results related to students' attitude towards claiming rights in terms of education level of fathers'.

\begin{tabular}{ccccccc}
\hline & $\begin{array}{c}\text { Sum of } \\
\text { Square }\end{array}$ & df & $\begin{array}{c}\text { Mean } \\
\text { square }\end{array}$ & F & p & $\begin{array}{c}\text { Differential } \\
\text { Groups }\end{array}$ \\
\hline Between Groups & 532,494 & 3 & 177,498 & 1,684 &, 169 & - \\
Within Groups & 72930,056 & 692 & 105,390 & & \\
Total & 73462,550 & 695 & & & \\
\hline
\end{tabular}
${ }^{*} \mathrm{p}<.05$

There was no significant difference between university students' attitudes towards claiming rights according to the education level of fathers. $(F(3-692)=1.684 ; p>0.01)$.

Table 4. One way ANOVA results related to students' attitude towards claiming rights in terms of education level of mothers'.

\begin{tabular}{ccccccc}
\hline & $\begin{array}{c}\text { Sum of } \\
\text { Square }\end{array}$ & df & $\begin{array}{c}\text { Mean } \\
\text { square }\end{array}$ & F & p & $\begin{array}{c}\text { Differential } \\
\text { Groups }\end{array}$ \\
\hline Between Groups & 437,012 & 3 & 145,671 & 1,380 &, 248 & - \\
Within Groups & 73025,538 & 692 & 105,528 & & \\
Total & 73462,550 & 695 & & & \\
\hline${ }^{*} \mathrm{p}<.05$ & & & &
\end{tabular}


There was no significant difference between university students' attitudes towards claiming rights according to the education level of the mother. $(F(3-692)=1,380 ; p>0.01)$.

\section{Students' Attitude towards Claiming Rights in terms of Family Income}

One-way ANOVA is used to compare whether the students' attitude towards claiming right in terms of family income. The results are indicated in Table 5.

Tablo 5. One way ANOVA results related to students' attitude towards claiming rights in terms of family income.

\begin{tabular}{ccccccc}
\hline & $\begin{array}{c}\text { Sum of } \\
\text { Square }\end{array}$ & df & $\begin{array}{c}\text { Mean } \\
\text { square }\end{array}$ & F & p & $\begin{array}{c}\text { Differential } \\
\text { Groups }\end{array}$ \\
\hline Between Groups & 82,010 & 3 & 27,337 &, 258 &, 856 & - \\
Within Groups & 71480,750 & 675 & 105,897 & & \\
Total & 71562,760 & 678 & & & \\
\hline${ }^{*} \mathrm{p}<.05$ & & & & & \\
\end{tabular}

There was no significant difference in the attitudes of university students towards claiming right according to the average income level of their families. $(F(3-675)=, 258 ; p>0.01)$.

\section{Students' Attitude towards Claiming Rights in terms of Faculty}

One-way ANOVA is used to compare whether the students' attitude towards claiming right in terms of faculty. The results are indicated in Table 6.

Tablo 6. One way ANOVA results related to students' attitude towards claiming rights in terms of faculty.

\begin{tabular}{ccccccc}
\hline & $\begin{array}{c}\text { Sum of } \\
\text { Square }\end{array}$ & df & $\begin{array}{c}\text { Mean } \\
\text { square }\end{array}$ & F & p & $\begin{array}{c}\text { Differential } \\
\text { Groups }\end{array}$ \\
\hline Between Groups & 1695,603 & 3 & 565,201 & 5,463 &, 000 & $\begin{array}{c}\text { Law-Engineering; } \\
\text { Law-medical school } \\
\text { and dentistry faculty }\end{array}$ \\
Within Groups & 72221,076 & 698 & 103,469 & & \\
Total & 73916,679 & 701 & & &
\end{tabular}

A significant difference was found in the attitudes of university students towards claiming rights according to the faculty $(\mathrm{F}(3-698)=5.463 ; \mathrm{p}<0.01)$. Faculty of Law students' attitudes towards claiming rights are more positive than students of engineering, medical and dentistry faculties. $(X$ meanlaw $=84,09>$ Xmeanengineering $=80,6$ and $X$ meanlaw $=84,09>$ Xmeanmedical school and dentistry $=82,4)$. When the effect size was examined, $\mathrm{n} 2=0.02$, eta square value was found. Since this value is greater than 0.01 (Cohen, 1988), it can be stated that the faculty attended has a moderate effect on students' attitudes towards claiming rights. There was no significant difference between the attitudes of faculty law and education students towards claiming rights $(\mathrm{p}>0.01)$.

\section{Students' Attitude towards Claiming Rights in terms of Grade}

One-way ANOVA is used to compare whether the students' attitude towards claiming right in terms of grade. The results are indicated in 7 .

Tablo 7. One way ANOVA results related to students' attitude towards claiming rights in terms of grade.

\begin{tabular}{ccccccc}
\hline & $\begin{array}{c}\text { Sum of } \\
\text { Square }\end{array}$ & df & $\begin{array}{c}\text { Mean } \\
\text { square }\end{array}$ & F & p & $\begin{array}{c}\text { Differential } \\
\text { Groups }\end{array}$ \\
\hline Between Groups & 1427,278 & 2 & 713,639 & 6,867 &, 0 & $\begin{array}{c}\text { 2. and 3. grade; } \\
\text { 2. and 4. grade }\end{array}$ \\
\hline
\end{tabular}




\begin{tabular}{cccc}
\cline { 2 - 3 } Within Groups & 72226,011 & 695 & 103,922 \\
Total & 73653,289 & 697 & \\
\hline${ }^{*} \mathrm{p}<.05$ & &
\end{tabular}

There was a significant difference in the attitudes of university students towards claiming rights according to their grades $(\mathrm{F}(2-695)=6.867 ; \mathrm{p}<0.01)$. 4 th grade students' attitudes towards claiming rights are more positive than 2nd and 3rd grade students (Xmean4th=83,55 $>$ Xmean2th= $77,47 ; \mathrm{Xmean} 3 \mathrm{th}=82,76>\mathrm{Xmean} 2 \mathrm{th}=77,47)$. When the effect size was examined, $\mathrm{n} 2=0.019$, eta square value was found. Since this value is close to 0.01 (Cohen, 1988), it can be stated that the grade level has a low level of effect on students' attitudes towards claiming rights. There was no significant difference between the attitudes of 2 nd and 3rd grade students towards claiming rights $(\mathrm{p}>0.01)$.

\section{Students' Attitude towards Claiming Rights in terms of Attitudes Of Parents}

One-way ANOVA is used to compare whether the students' attitude towards claiming rights in terms of attitudes of their parents'. The results are indicated in Table 8 and Table 9.

Table 8. One way ANOVA results related to students' attitude towards claiming rights in terms of education attitudes of mothers'.

\begin{tabular}{ccccccc}
\hline & $\begin{array}{c}\text { Sum of } \\
\text { Square }\end{array}$ & $d f$ & $\begin{array}{c}\text { Mean } \\
\text { square }\end{array}$ & $\boldsymbol{F}$ & $\boldsymbol{p}$ & $\begin{array}{c}\text { Differential } \\
\text { Groups }\end{array}$ \\
\hline Between Groups & 1048,482 & 4 & 262,121 & 2,511 &, 041 & Democratic \\
Within Groups & 71305,169 & 683 & 104,400 & & Authoritarian \\
$\quad$ Total & 72353,651 & 687 & & & \\
\hline${ }^{*} \mathrm{p}<.05$ & & & &
\end{tabular}

A significant difference was found in students' attitudes towards claiming rights according to their mother attitudes $(\mathrm{F}(4-683)=2.511 ; \mathrm{p}<0.05)$. Students who state that their mothers have a democratic attitude have more positive attitudes towards claiming rights than students with authoritarian mothers. $\left(X_{\text {meandemocratic }}=82,85>X_{\text {mean }}\right.$ authoritarian $\left.=79,20\right)$. No significant difference was found between the attitudes of the students with irrelevant, inconsistent and authoritarian mother attitudes towards claiming rights.

Table 9. One way ANOVA results related to students' attitude towards claiming rights in terms of education attitudes of fathers'.

\begin{tabular}{|c|c|c|c|c|c|c|}
\hline & $\begin{array}{l}\text { Sum of } \\
\text { Square }\end{array}$ & df & Mean square & $\mathbf{F}$ & p & $\begin{array}{c}\text { Differential } \\
\text { Groups }\end{array}$ \\
\hline \multirow[t]{4}{*}{ Between Groups } & & & & & & Democratic- \\
\hline & 2155,802 & 4 & 538,950 & 5,223 & ,000 & Irrelevant; \\
\hline & & & & & & Irrelevant- \\
\hline & & & & & & Authoritarian \\
\hline Within Groups & 70163,226 & 680 & 103,181 & & & \\
\hline Total & 72319,028 & 684 & & & & \\
\hline
\end{tabular}

A significant difference was found in students' attitudes towards claiming rights according to their father attitudes $(\mathrm{F}(4-680)=5.223 ; \mathrm{p}<0.01)$. Students who stated that their fathers had an indifferent attitude towards claiming rights were more negative than students with authoritarian and democratic fathers $(X$ meandemocratic $=83,23>X$ meanauthoritarian $=81,49 ; X$ meandemocratic $=83,23>X$ meanirrelavant $=75,45)$. When the effect size was examined, $\mathrm{n} 2=0.02$, eta square value was found. Since this value is greater than 0.01 (Cohen, 1988), it can be stated that the father's attitude has a moderate effect on students' attitudes towards claiming rights. No significant difference was found between the attitudes of students with democratic and authoritarian father attitudes towards claiming rights. 


\section{Students' Attitude towards Claiming Rights in terms of Type Of High School They Graduated From}

One-way ANOVA is used to compare whether the students' attitude towards claiming rights in terms of type of high school they graduated from. The results are indicated in Table 10.

Tablo 10. One way ANOVA results related to students' attitude towards claiming rights in terms of type of high school they graduated from.

\begin{tabular}{|c|c|c|c|c|c|c|}
\hline & $\begin{array}{l}\text { Sum of } \\
\text { Square }\end{array}$ & $\mathrm{df}$ & $\begin{array}{l}\text { Mean } \\
\text { square }\end{array}$ & $\mathbf{F}$ & p & $\begin{array}{c}\text { Differential } \\
\text { Groups }\end{array}$ \\
\hline Between Groups & 888,330 & 4 & 222,083 & 2,114 &, 077 & - \\
\hline Within Groups & 73125,479 & 696 & 105,065 & & & \\
\hline Total & 74013,809 & 700 & & & & \\
\hline
\end{tabular}

There was no significant difference in the attitudes of university students towards claiming rights according to the type of high school they graduated from. ( $F(4-696)=2.114 ; p>0.01)$.

Students' Attitude towards Claiming Rights in terms of Type of University

Table 11. $\mathrm{t}$ test result related to students' attitude towards claiming rights in terms of type of university

\begin{tabular}{ccccccc}
\hline University & $\mathbf{n}$ & $\mathbf{M}$ & $\mathbf{S}$ & $\mathbf{s d}$ & $\mathbf{t}$ & $\mathbf{p}$ \\
\hline State & 352 & 82,3 & 10,2 & 709 &,- 526 &, $599^{*}$ \\
Private & 359 & 83,7 & 9,6 & & & \\
\hline${ }^{*} \mathrm{p}>.05$ & & & & &
\end{tabular}

There was no significant difference in the attitudes of university students towards claiming rights according to the type of university $(\mathrm{t}(709)=-, 526 ; \mathrm{p}>0.01)$.

\section{Results and Discussion}

When the averages obtained from the scale regarding the attitudes of claiming right of university students are analyzed, it is seen that their attitudes to claiming right are above the average. A culture of democracy can be formed by active individuals who claim their rights, who do not refrain from struggling to obtain what they deserve, and who can implement their democratic values.

Activities such as creating public pressure, using the right to demonstrate and march, and participating in non-governmental organizations, which are defined as other ways to seek rights, are actually activities that prepare the ground for the establishment of a culture of democracy in the society. In other words, the widespread use of such remedies can be interpreted as a culture of democracy and belief in justice in the society. In this respect, the fact that the attitudes of university students claiming right are above average in the present study shows that the perspective of rights and justice among young people is developing.

Similarly, Akın and Özdemir (2009) found that teacher candidates who are members of nongovernmental organizations have more democratic values than those who are not members of such organizations. In addition, Köse (2015) stated that the activism culture acquired by students working in student youth organizations has become one of the most important components of their way of life and that they want to continue to be involved in various organizations such as parties, unions, organizations and associations.

In addition to these studies indicating the importance of justice and claiming rights, there are also studies stating that individuals do not turn their attitude of claiming right into action.

Çermik (2013) states that teacher candidates put justice as the highest democratic value in their lives, but they do not have the same high value in claiming rights. Türkbay (2005) states that the level of participation in activities such as political meetings and association activities among students is extremely low. Dündar and 
Deniz (2010) revealed that students' perspectives on citizenship are basically based on the fact of being conscious, but they do not make this perspective functional. Also Eryllmaz, Bursa, and Ersoy (2018) concluded that teachers and students do not consider participating in non-governmental organizations within the scope of effective citizenship and that students' knowledge and experience of non-governmental organizations are limited. Yöneten-Balaban and Çoban-İnce (2015) also stated that the participation rate of young people in civil society organizations is low.

When the results of this study are evaluated in terms of gender, a significant difference was found in the attitudes of university students towards claiming rights. Female students' attitudes towards claiming rights were found to be more positive than male students. It can be said that this result of the study is in parallel with the findings of the research in which the democratic attitudes of female students are higher (Akın \& Özdemir, 2009; Aydemir \& Aksoy, 2010; Büyükkaragöz, 1995; Demoulin \& Kolstad, 2000; Dilekmen, 2000; Ekici, 2014; Erdem \& Sarıtas 2006; Genç ve Kalafat, 2007, 2008; Gömleksiz ve Çetintaş, 2011; Gömleksiz \& Kan, 2008; Karahan \& ark., 2006; Saraçoğlu \& diğ., 2004; Şen, 2006; Ulusoy, 2007; Yanardağ, 2000).

On the other hand, Ada \& Koç (2000), Bulut (2006), Dilekmen (2000), Ektem \& Sünbül (2011), Elkatmış \& Toptaş (2015), Ercoşkun \& Nalçacı (2008), Karahan \& et al. (2006), Kılıç \& et al. (2004), Ömerustaoğlu (2004), Şahan (2018), Toy (2004), and Yilmaz (2009) found in their research that the democratic attitudes of students who did not coincide with these results did not differ significantly according to their gender.

When both results are considered together, it can be concluded that the gender variable is not clear enough to reflect the atttute of claiming right. In addition, all of the studies examined the democratic attitudes of prospective Faculty of education students. In the present study, considering that different faculties and universities were included in the study, it is significant that the attitudes of female students towards claiming rights are found more positive than male students. Considering the fact that women in our society are increasingly exposed to psychological and physical violence both in their professional and private lives; It is a positive development that female students' attitudes to claiming right are high.

When the results of this study are evaluated in terms of parents' education level, there was no significant difference in the attitudes of university students towards claiming rights. In the research of Dolmacı and Kuşat (2005), it was concluded that the awareness of claiming justice does not differ according to the education levels of the parents. Similarly, in the research conducted by Elkatmış and Toptaş (2015), Ekici (2014) and Genç and Kalafat $(2007,2008)$, it was revealed that the education levels of parents are not effective in developing democratic attitudes in individuals. Likewise, in the researches of Gömleksiz and Çetintaş (2011), Aydemir and Aksoy (2010), Ömerustaoğlu (2004) and Bulut (2006), it was determined that the democratic attitudes of teacher candidates did not change according to the education level of parents.

Özbek (2004), Bulut (2006), Gömleksiz and Kan (2008), Saraçoğlu and Others (2004) reached the conclusion that teacher candidates whose parents have high education levels also have higher democratic attitude scores. In the research of Gömleksiz and Çetintaş (2011), it is stated that the democratic attitudes of teacher candidates whose mothers are illiterate; It was found that it is higher than teacher candidates whose mothers are primary, secondary, high school and university graduates. When both results are considered together, it can be concluded that the gender variable is not clear enough to reflect the attitude of claiming right.

One of interesting result of this study is that students' attitude towards claiming right do not differ in terms of average income level of their families. Bulut (2006); The research results of Ekici (2014), Aydemir and Aksoy (2010), Ömerustaoğlu (2004), Akın and Özdemir (2009) and Elkatmış and Toptaş (2015) also coincide with this result. When other studies on the subject were examined, different findings were found. In the research of Gömleksiz and Çetintaş (2011), it was determined that the democratic attitudes of teacher 
candidates differ according to the income level of their families, and the democratic attitudes of the teacher candidates whose families are at the middle and low income level were found to be more positive than the democratic attitudes of the high-income. Different from this, in the research conducted by Shirtless and Kan (2008), it was found that the increase in the family's income level positively affected the democratic attitude of the individual. When both results are considered together, it can be concluded that the variable of average income level is not clear enough to reflect the attitude of claiming right.

When the results of this study are evaluated in terms of faculty, a significant difference was found in the attitudes of students towards claiming rights. Faculty of Law students' attitudes towards claiming rights are more positive than students of engineering, medical and dentistry faculties. There was no significant difference between the attitudes of faculty of law and faculty of education students towards claiming rights. In a similar study, Türkbay (2005) found that social sciences students supported the active political activities of students more than science students and were more sensitive to limiting the freedom of association. According to the results of the same research, it was seen that social sciences students had a more democratic attitude, both on average and statistically, compared to science students.

The fact that law faculty students' attitudes towards claiming rights are found to be more positive compared to other faculties can be associated with the curriculum of the law faculty. Based on this, it would not be wrong to say that, regardless of whether it is social sciences or natural sciences, introducing informative lectures on law to each faculty will contribute to developing a positive attitude towards claiming rights.

When the results of this study are evaluated in terms of grade, a significant difference was found in the attitudes of students towards claiming rights. 4th grade students' attitudes towards claiming rights are more positive than 2nd and 3rd grade students. In a similar study (Türkbay, 2005), it was found that senior students value freedom more and have a more democratic attitude than first year students. In the research of Young and Kalafat $(2007,2008)$, it was observed that the democratic attitudes of the teacher candidates did not differ according to the class level.

This result obtained from the present study can be interpreted as the increased level of knowledge and awareness during higher education also positively affects the attitudes of students to claiming right.

When the results of this study are evaluated in terms of parents' attitudes., a significant difference was found in the attitudes of students towards claiming rights. Students whose mothers have a democratic attitude towards claiming rights are more positive than students whose mothers have an authoritarian attitude. No significant difference was found between the attitudes of the students with indifferent, inconsistent and authoritarian mother attitudes towards claiming rights. Students whose fathers have an indifferent attitude towards claiming rights are more negative than students whose fathers have an authoritarian and democratic attitude. There was no significant difference between the attitudes of students with democratic and authoritarian father attitudes towards claiming rights. In Bulut's (2006) research, the attitudes of students with parents with a democratic attitude were found to be more democratic. According to this result, it can be said that individuals' democratic attitudes will be positively affected in families with democratic life style and values.

One of interesting result of this study is that students' attitude towards calaiming right do not differ in terms of the type of high school they graduated from. This result is similar to the studies of Bulut (2006) and Elkatmış and Toptaş (2015). In the study of Saraçoğlu et al. (2004), it was observed that the democratic attitude levels of the students differed statistically according to the type of high school graduated from. Similarly, in the study conducted by Dolmacı and Kuşat (2015), a significant difference was found according to the type of high school that the participants graduated in terms of awareness of claiming remedies. When both results are 
considered together, it can be concluded that the high school type variable is not sufficiently distinct in reflecting the attitude of claiming right.

\section{Conclusion}

These results, which show that university students' attitudes of claiming right are positive, are important for university students to be active and participatory citizens. Individuals who will create the culture of democracy in the society and at the same time protect this democratic society structure will be individuals who have democratic values and implement them in their lives. Individuals who claim their rights, question, criticize, express their opinions and defend themselves can be expressed as individuals who can put their democratic values into action. Having democratic values will not make sense for the individual and the society in which they live, unless these democratic values are put into practice. While the education system has a role in the perception and acquisition of democratic values; the justice system plays a major role in the implementation of democratic values and the healthy functioning of remedial processes. The knowledge required for conscious and active citizenship should be provided to individuals by including all stakeholders of the system at every stage of the education process, without leaving it to higher education. The culture of democracy should be established in educational organizations by supporting the course contents with school culture. With the changes to be made in this way, positive claiming right attitudes that turn democratic values into action will be established.

\section{Limitations and Further Study}

The descriptive data obtained quantitatively in the present study are superficial. Similar studies can be done using qualitative methods. In addition, university students studying at law faculties, engineering faculties, medical Faculty/Faculty of dentistiry and faculty of education were included in the present study. Similar studies can be conducted by including different faculties and colleges. In addition, studies can be conducted to reveal the relationships between the attitude of claiming remedies and various concepts. 


\section{REFERENCES}

Ada, Ş. ve Koç, M. (2000, Eylül). Üniversite öğrencilerinin lisans eğitimleri süresince demokratik tutumlardaki değişmelerin çeşitli değişkenler açısından incelenmesi, IX. Ulusal Ĕ̆itim Bilimleri Kongresi Bildiri Kitabı içinde (796-808). Atatürk Üniversitesi Kazım Karabekir Eğitim Fakültesi, Erzurum.

Akçay, P. ve Güler, G. (2021). Hak arama tutum ölçeğinin geçerlik ve güvenirlik çalışması, Anadolu Journal of Educational Sciences International, 12(2).

Akdağ, B. (1999). Eğitim hakkı ve özgürlüğü üzerine, Eğitim ve Yaşam Dergisi, 4, 15-18.

Akın, İ. (1974). Kamu hukuku. İstanbul: Fakülteler Matbaası.

Akın, U. ve Özdemir, M. (2009). Öğretmen adaylarının demokratik değerlerinin çeşitli değişkenler açısından incelenmesi: Eğitim bilimleri fakültesi örneği, Ankara Üniversitesi Eğitim Bilimleri Fakültesi Dergisi, 42(2), 183-198.

Aktan, C. C. ve Çoban, H. (2006). Kurumsal devlet yönetimi-iyi devlet yönetimi için kurallar ve kurumlar, kamu sektöründe iyi yönetim ilkeleri, Sermaye Piyasası Kurulu Kurumsal Araştırmalar Serisi 5(197), 17-53. Ankara: SPK Yayınları.

Akyüz, E. (2001). Çocuk hakları sözleşmesinin temel ilkeleri 1şığında çocuğun eğitim hakkı. http://yayim.meb.gov.tr/dergiler/151/akyuz.htm, 29.11.2017.

Aydemir, H., ve Aksoy, N.D. (2010). Eğitim fakültesi öğrencilerinin demokratik tutumlarının bazı değişkenlerle ilişkisi: Malatya örneği. Erzincan Eğitim Fakültesi Dergisi, 12(1), 265-279.

Bulut, N. (2006). Bir grup üniversite öğrencisinin demokratik tutumları ile çeşitli değişkenler arasındaki ilişkiler. Kuram ve Uygulamada Ĕ̆itim Yönetimi, 45, 37-59.

Büyükkaragöz, S. (1995). Yükseköğretim programları ve demokratik tutumlar. Ankara: Türk Demokrasi Vakfı Yayınları.

Büyüköztürk, Ş., Kılıç Çakmak, E., Akgün, Ö. E., Karadeniz, Ş. ve Demirel, F. (2019) Eğitimde bilimsel araştırma yöntemleri. (27. Bask1). Ankara: Pegem Akademi.

Çermik, H. (2013). Öğretmen adaylarının demokratik değerleri ve bu değerlerin bazı değişkenler açısından incelenmesi, E-Journal of New World Sciences Academy, Education Sciences, 8(2), 261-274.

Çıngı, H., ( 1994). Örnekleme kuramı. Ankara: Hacettepe Üniversitesi Fen Fakültesi Basımevi.

Demoulin, D.F. \& Kolstad, R. (2000). Assessing the gains of behavioral dynamics essential for success in democracy for teacher education students. College Student Journal, 34(3), 417-424.

Dilekmen, M. (2000). Sınıf öğretmenliği öğretmen adaylarının demokratik tutumlarının çeşitli değişkenler açısından incelenmesi. II. Ulusal Öğretmen Yetiştirme Sempozyumu Bildiri Kitabı içinde (s. 438-442). Çanakkale Onsekiz Mart Üniversitesi: Çanakkale.

Dolmacı, N. ve Kuşat, N. (2015). Üniversite gençliğinin vatandaşlık hak ve sorumluluklarına ilişkin bilinç ve farkındalıkları üzerine bir araştırma: Isparta meslek yüksekokulu örneği. Muhasebe ve Finansman Dergisi, 65, 161-180.

Dündar, İ. P. ve Deniz, D. (2010). Vatandaşlık bilinci üzerine: Ege üniversitesi, iletişim fakültesi öğrencilerinin bilgi, vatandaşlık ve sivil toplum kurulularına bakış açılarını sorgulayan bir araştırma. Uluslararası Sosyal Araştırmalar Dergisi, 3(12), 128-139. 
Ekici, F. Y. (2014). Öğretmen adaylarının demokratik tutumları ve demografik özellikleri arasındaki ilişkinin incelenmesi. Turkish Studies International Periodical For the Languages, Literature and History of Turkish or Turkic, (9)11, 593-602.

Ektem, I. S. ve Sünbül, A. M. (2011). Öğretmen adaylarının demokratik tutumları üzerine bir araştırma, Selçuk Üniversitesi Ahmet Keleşoğlu Eğitim Fakültesi Dergisi, 31, 159- 168.

Elkatmış, M. ve Toptaş, V. (2015). Sınıf öğretmeni adaylarının demokratik tutumlarının incelenmesi. YYÜ Eğitim Fakültesi Dergisi, 12(1), 128-144.

Ercoşkun, M. H. ve Nalçacı, A. (2008).Sınıf öğretmeni adaylarının empatik beceri ve demokratik tutumlarının incelenmesi. Milli Ĕ̆gitim, 180, 204-215.

Eryılmaz, Ö., Bursa S. ve Ersoy, A. F. (2018). Sosyal bilgiler öğretmenleri ve öğrencilerinin etkin vatandaşlık ile sivil toplum kuruluşu algıları, International Online Journal of Educational Sciences, 10(2), 258-276.

Erdem, A.R. ve Sarıtaş, E. (2006). Sınıf öğretmenliği öğrencilerinin öğretim elemanlarının davranışlarının demokratikliğine ilişkin algıları (PAÜ örneği). Selçuk Üniversitesi Sosyal Bilimler Enstitüsü Dergisi, 16.

Fraenkel, J. R., Wallen, N. E. \& Hyun, H. (2015). How to design and evaluate research in education. New York McGraw-Hill Humanitie.

Genç, S. Z. ve Kalafat, T. (2007). Öğretmen adaylarının demokratik tutumları ile problem çözme becerilerinin çeşitli değişkenler açısından incelenmesi. Pamukkale Üniversitesi Eğitim Fakültesi Dergisi, 2, 22.

Genç, S. Z. ve Kalafat, T. (2008). Öğretmen adaylarının demokratik tutumları ile empatik becerilerinin değerlendirilmesi üzerine bir araştırma, Manas Üniversitesi Sosyal Bilimleri Dergisi, 19, 211-222.

Gölcüklü, F. A. ve Gözübüyük, Ş. A. (2002). Avrupa İnsan hakları sözleşmesi ve uygulaması (3. Baskı). Ankara: Turhan Kitabevi.

Gömleksiz, M. N. ve Kan A. Ü. (2008). Eğitim fakültesi ve tezsiz yüksek lisans programlarına kayıtlı öğretmen adaylarının demokratik tutumlarının değerlendirilmesi, Fırat üniversitesi örneği. Milli Ĕ̆itim, 178, 4463.

Gömleksiz, M. N. ve Çetintaş, S. (2011). Öğretmen adaylarının demokratik tutumları (Cumhuriyet ve Erzincan Üniversiteleri Örneği). Dicle Üniversitesi Ziya Gökalp Eğitim Fakültesi Dergisi, 17, 1-14.

Güran, S. (1993). Hak arama özgürlüğünün iki boyutu. (son erişim tarihi 01.09.2018) http://www.anayasa.gov.tr.

İzgi, Ö. ve Gören, Z. (2002). Türkiye Cumhuriyeti Anayasası'nın yorumu. Ankara: TBMM Basımevi.

Kaboğlu, İ. Ö. (1999). Özgürlükler hukuku: İnsan haklarının hukuksal yapısl, (5. Bask1). İstanbul: Afa.

Karahan, T. F., Sardogan, M. E., Özkamalı, E. ve Dicle, A. N. (2006). Öğretmen adaylarında demokratik tutum, nevrotik eğilimler ve kendini gerçekleştirme. Hacettepe Üniversitesi Eğitim Fakültesi Dergisi, 30, 149-158.

Karasar, N. (2011). Bilimsel araştırma yöntemleri. Ankara: Nobel Yayınları.

Karaman Kepenekçi, Y. (2007) Eğitimin hukuki temelleri (Ed. M. D. Karslı). Eğitim Bilimine Giriş içinde (s. 5176). Ankara: PegemA Yayıncilik.

Keyman, F. (2004) Türkiye'de ve Avrupa'da sivil toplum. İstanbul Bilgi Üniversitesi, STK Eğitim ve Araştırma Birimi, Sivil Toplum ve Demokrasi Konferans Yazları, 3.

Köse, E. (2015). Üniversite gençlerinin toplumsal hareketlere katıllm biçim ve dinamikleri: Ankara'da bir grup üniversite öğrencisi üzerine bir araştırma. Yayımlanmamış Yüksek Lisans Tezi. Hacettepe Üniversitesi Sosyal Bilimler Enstitüsü, Ankara. 
Ömerustaoğlu, A. (2004). Ö. Felsefe grubu öğretmenleri ve diğer anabilim dallarında öğrenim gören öğrencilerin demokratik tutumlarının çeşitli değişkenler açısından incelenmesi. Sakarya Üniversitesi Eğitim Fakültesi Dergisi, 7, 216-226.

Özbek, R. (2004). Vatandaşlık ve insan hakları eğitimi amaçlarının gerçekleşme düzeyine ilişkin öğretmen ve öğrenci tutumlarının değerlendirilmesi. Uluslararası Demokrasi Eğitimi Sempozyumu Bildiriler Kitabı içinde (s. 386-396). Çanakkale: Çanakkale Onsekiz Mart Üniversitesi Yayınları.

Özbilgen, T . (2011). Hukukun sosyolojik oluşum prosesü açısından bir örnekleme olarak hak arama yolları. Istanbul Journal of Sociological Studies, 0(13), 50-72.

Saracaloğlu, S. A., Evin, İ., ve Varol, S. R. (2004). İzmir ilinde çeşitli kurumlarda görev yapan öğretmenler ile öğretmen adaylarının demokratik tutumları üzerine karşılaştırmalı bir araştırma. Kuram ve Uygulamada Ĕ̆itim Bilimleri, 4(2), 335-364.

Şahan, G. (2018). Formasyon eğitimi alan öğretmen adaylarının demokratik tutumlarının değerlendirilmesi. Turkish Studies Volume 13(4), 1045-1056.

Tabachnick, B. G. \& Fidel, S. L. (2001). Using multivariate statistics. New York: Harper Collin.

Tanör, B. ve Yüzbaşığlu, N. (2001). 1982 Anayasasına göre Türk anayasa hukuku, (2. Baskı). İstanbul: Yapı Kredi Yayınları.

Tanyar Z. Ç. (2011). Avrupa İnsan Hakları Mahkemesi içtihadında toplantı ve gösteri yürüyüşü hakkı, AÜHFD, 60(3) 593-634.

Türkbay, R. A. (2005). Üniversite öğrencilerinin demokratik tutum ve değerleri üzerine bir araştırma (Pamukkale üniversitesi örneği). (Yayımlanmamış yüksek lisans tezi). Pamukkale Üniversitesi Sosyal Bilimler Enstitüsü, Denizli.

Ulusoy, K. (2007). Lise tarih programımda yer alan geleneksel ve demokratik değerlere yönelik öğrenci tutumlarının ve görüşlerinin çeşitli değişkenler açısından değerlendirilmesi. (Yayımlanmamış doktora tezi). Gazi Üniversitesi Eğitim Bilimleri Enstitüsü, Ankara.

Uyar, L. (2006). Birleşmiş Milletlerde insan hakları yorumları. İnsan Hakları Komitesi ve Ekonomik, Sosyal ve Kültürel Haklar Komitesi 1981 - 2006. İstanbul: İstanbul Bilgi Üniversitesi Yayınları.

Yanardağ, A. (2000). Üniversite gençliğinin demokratik tutum ve davranışlarn üzerine bir araştırma (Selçuk üniversitesi örneği). (Yayımlanmamış yüksek lisans tezi). Sakarya Üniversitesi Sosyal Bilimler Enstitüsü, Sakarya.

Yaşar, N. (2000). İnsan hakları Avrupa sisteminde ve Türk hukukunda eğitim hakkı ve özgürlüğü. İstanbul: Filiz Kitabevi.

Yöneten Balaban, A. ve Çoban İnce, İ. (2015) Gençlerin sivil toplum kuruluşlarındaki gönüllülük faaliyetleri ve gönüllülük algısı: Türkiye Eğitim Gönüllüleri Vakfı (TEGV) Örneği. Dokuz Eylül Üniversitesi, Iktisadi ve Idari Bilimler Fakültesi Dergisi, 30(2), 149-169. 